\title{
Evaluation of Hydra HALT-1 as a toxin moiety for recombinant immunotoxin
}

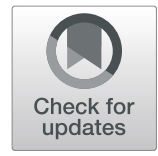

William F. Jiemy', Lih Fhung Hiew², Hong Xi Sha ${ }^{2}$, Lionel L. A. In ${ }^{1}$ and Jung Shan Hwang ${ }^{3^{*}}$ (D)

\begin{abstract}
Background: Immunotoxin is a hybrid protein consisting of a toxin moiety that is linked to a targeting moiety for the purpose of specific elimination of target cells. Toxins used in traditional immunotoxins are practically difficult to be produced in large amount, have poor tissue penetration and a complex internalization process. We hypothesized that the smaller HALT-1, a cytolysin derived from Hydra magnipapillata, can be used as the toxin moiety in construction of a recombinant immunotoxin.

Results: In this study, pro-inflammatory macrophage was selected as the target cell due to its major roles in numerous inflammatory and autoimmune disorders. We aimed to construct macrophage-targeted recombinant immunotoxins by combining HALT-1 with anti-CD64-scFv in two orientations, and to assess whether their cytotoxic activity and binding capability could be preserved upon molecular fusion. The recombinant immunotoxins, HALT-1-sCFv and sCFv-HALT-1, were successfully constructed and expressed in Escherichia coli (E. coli). Our data showed that HALT-1 still exhibited significant cytotoxicity against CD64 ${ }^{+}$and $\mathrm{CD}^{-} 4^{-}$cell lines upon fusion with anti-CD64 scFv, although it had half cytotoxic activity as compared to HALT-1 alone. As positioning HALT-1 at N- or C-terminus did not affect its potency, the two constructs demonstrated comparable cytotoxic activities with $\mathrm{IC}_{50}$ lower in $\mathrm{CD}^{+} 4^{+}$cell line than in $\mathrm{CD}^{-} 4^{-}$cell line. In contrast, the location of targeting moieties anti-CD64 scFv at C-terminal end was crucial in maintaining the scFv binding capability.

Conclusions: HALT-1 could be fused with anti-CD64-scFv via a fsexible polypeptide linker. Upon the successful production of this recombinant HALT-1 scFv fusion protein, HALT-1 was proven effective for killing two human cell lines. Hence, this preliminary study strongly suggested that HALT-1 holds potential as the toxin moiety in therapeutic cell targeting.
\end{abstract}

Keywords: Actinoporin, Cnidaria, a-Pore forming toxin, Proinflammatory, Single chain fragment variable, Immunotoxin

\section{Background}

Immunotoxin, often termed "targeted therapy", is a hybrid protein consisting of a toxin moiety that is linked to a targeting moiety for the purpose of specific elimination of the target cells. The targeting moiety is generally a monoclonal antibody or genetically engineered antibody fragments. The first generation immunotoxins were

\footnotetext{
*Correspondence: hwangjs@sunway.edu.my

${ }^{3}$ Department of Medical Sciences, School of Healthcare and Medical

Sciences, Sunway University, No. 5, Jalan Universiti, Bandar Sunway, 47500

Selangor Darul Ehsan, Malaysia

Full list of author information is available at the end of the article
}

created by chemically conjugating a monoclonal antibody with a toxin moiety. However, the first generation immunotoxins were large and therefore ineffective in tissue penetration and induced immunogenicity in the host [1]. The latest generation of recombinant immunotoxins were constructed by linking the gene encoding singlechain variable fragment $(\mathrm{scFv})$ with the gene encoding the toxin moiety and expressing them in host cells. Although the latest generation of immunotoxins significantly reduce the molecular weight of the targeting moiety, the toxins commonly used are still too large. Most of these toxins such as RicinA, Pseudomonas

(c) The Author(s). 2020 Open Access This article is licensed under a Creative Commons Attribution 4.0 International License, which permits use, sharing, adaptation, distribution and reproduction in any medium or format, as long as you give appropriate credit to the original author(s) and the source, provide a link to the Creative Commons licence, and indicate if changes were made. The images or other third party material in this article are included in the article's Creative Commons licence, unless indicated otherwise in a credit line to the material. If material is not included in the article's Creative Commons licence and your intended use is not permitted by statutory regulation or exceeds the permitted use, you will need to obtain permission directly from the copyright holder. To view a copy of this licence, visit http://creativecommons.org/licenses/by/4.0/ The Creative Commons Public Domain Dedication waiver (http://creativecommons.org/publicdomain/zero/1.0/) applies to the data made available in this article, unless otherwise stated in a credit line to the data. 
exotoxin, and diphtheria toxin are $30-58 \mathrm{kDa}$ and require internalization to the cytosol of target cells to work [1]. These properties lead to disadvantages such as low tissue penetration rate, defect in cytosol delivery and degradation of the immunotoxin in lysosomes before exerting their effect $[2,3]$. A smaller sized toxin with no internalization process could eliminate these disadvantages.

HALT-1 (Hydra actinoporin-like toxin 1), a poreforming toxin derived from Hydra magnipapillata, could be a new candidate for the toxin moiety in the recombinant immunotoxin [4]. HALT-1 resembles actinoporin, a family of $\alpha$-pore forming toxins ( $\alpha$-PFTs) first identified in sea anemones but also found in other cnidarians [5]. Actinoporins such as equinatoxins and sticholysins bind to sphingomyelins on the cell membrane and create functional pores by oligomerization of four or more than four monomers, leading to an osmotic imbalance in the cell and subsequently cell lysis [6, 7]. Early attempts have been made to use equinatoxin II and sticholysin I \& II as immunotoxins for anti-parasite and anti-cancer therapy [8-10]. One of these early immunotoxins was based on the disulphite linkage between the sticholysin and the monoclonal antibody IOR-T6 that bound directly to the antigen on the surface of immature T-lymphocytes [8]. This immunotoxin was highly toxic for IOR-T6 carrying cells (CEM) and not toxic for non-IOR-T6 cells (K562). Under reducing condition, sticholysin was released from immunotoxin and able to equally kill both cell types [8]. Another "prototype" used avidin and biotinylated secondary antibody to link two separate moieties, anti-Giardia antibody and biotinylated equinatoxin II, in the anti-Giardia assay [9]. The authors demonstrated quite promising results with respect to the specificity of the toxic effect of actinoporins on parasite cells. Although these actinoporin-based immunotoxins belong to the first or second generations of immunotoxin in which the targeting and toxin components are chemically conjugated in vitro, the actinoporins could exert cytolytic activity against targeted cells and were proven as good candidates for constructing immunotoxins. In recent studies, actinoporin is also known to cause cell death in a regulated manner. For example, intracellular ion imbalance that was due to the low-dose exposure of sticholysin II could activate the RIP1-MEK1/2ERK1/2-pathways and subsequently induce the regulated necrosis-like cell death mechanism $[11,12]$. Hence, actinoporins including HALT-1 are versatile proteins with multiple modes of action. Moreover, compared to other toxins used for the construction of immunotoxins, actinoporin or HALT-1 is much smaller in size $(20.8 \mathrm{kDa})$ and works by forming pores on cell membrane, which may provide a solution to overcome the disadvantages of other toxins.

Macrophages have been identified as one of the major cellular players in the pathogenesis of numerous chronic inflammatory disorders including vasculitis [13], atherosclerosis [14], rheumatoid arthritis [15], systemic lupus erythematosus [16], making them an attractive target for immunotoxin development. A study by Thepen et al. [17] demonstrated a successful reduction of chronic cutaneous inflammation in a mice model by targeting inflammatory macrophages using CD64 targeted immunotoxin, H22-RicinA. Generally, macrophages are categorized into two distinct phenotypes, which are the M1 (classically activated, proinflammatory) and M2 (alternatively activated, tissue remodelling) macrophages $[13,15,18]$. It is important to note that the M1/M2 paradigm of macrophage polarization is an oversimplified classification based on in vitro model, which may not directly resemble macrophage behaviour in vivo. Nonetheless, strong activity of pro-inflammatory cytokines and reactive species, which clearly resembles the skew towards M1-like activation, has been associated with the development of persistent chronic inflammation [19]. Therefore, M1-like macrophages may serve as a potent therapeutic target for reducing chronic inflammation. Activated macrophages express a wide variety of cell surface markers. In general, these markers are expressed on both M1 and M2 macrophages. However, some markers are expressed in greater quantity on M1 macrophage and are downregulated on M2 macrophage. An example of such receptor is CD64 (Fc gamma receptor 1), a high-affinity immunoglobulin Fc receptor [20]. The high expression of CD64 on M1-like macrophages makes this receptor an attractive target for specific elimination of M1-like proinflammatory macrophages. Additionally, evidence has shown that CD64 is only expressed on myeloid cell lines including monocytes, macrophages and activated neutrophils [21, 22]. Numerous other studies have also shown reduction of inflammation with CD64 targeted immunotoxin further confirming the utility of CD64 as a target for immunotoxin development [23-25].

We hypothesized that HALT-1 could be used as a toxin moiety for the construction of recombinant immunotoxin. In this study, we described for the construction of HALT-1-based recombinant immunotoxins by molecular fusion of HALT-1 with anti-CD64 scFv in two different orientations. We then determined the binding potential of the two immunotoxins to CD64 in vitro. Moreover, the efficacy of these recombinant immunotoxins against M1-like macrophages and HeLa cells was evaluated in terms of the cytotoxicity of HALT-1, but not the selective binding affinity of scFv to cells expressing CD64 since the immunotoxins could recognise both M1-like macrophages and HeLa cells via HALT-1. Our findings suggested the potential of using HALT-1 as toxin moiety for construction of recombinant immunotoxins with preferable arrangement of HALT-1 at the N- 
terminal end. As the binding specificity of scFv to CD64 could have been masked by HALT-1 which recognises the membrane lipids of almost all human cell types, the immunotoxins did not differentiate $\mathrm{CD}_{64}{ }^{+}$M1-like macrophages from CD64 ${ }^{-} \mathrm{HeLa}$ cells. Hence, the future study should replace HALT-1 with a mutant lacking the binding affinity to membrane lipids.

\section{Results}

\section{In vitro assessment of $a-\mathrm{CD} 64-\mathrm{scFv}$ (or scFv) binding to} CD64

CD64 has been shown to be a good choice of target for the development of therapies against many kinds of monocyte/macrophages related inflammatory diseases such as rheumatoid arthritis, inflammatory skin diseases and acute myeloid leukemia (AML). $\alpha$-CD64-scFv used in our study is based on the amino acid sequence of
$\mathrm{H} 22(\mathrm{scFv})$ that was reported to show specific binding towards CD64 [26-28]. $\alpha-\mathrm{CD} 64-\mathrm{scFv}$ was expressed as a recombinant protein in BL21(DE3) E. coli cells and its solubility was assessed before the purification. Soluble lysate of expressed culture was compared with the insoluble cell debris on SDS-PAGE (Fig. 1a). Our results showed $\alpha$-CD64-scFv present as an insoluble $32 \mathrm{kD}$ protein. Hence it was purified under denaturing condition and then followed by refolding. The final yield of recombinant $\alpha$-CD64-scFv was $144 \mu \mathrm{g} / \mathrm{mL}$ (Fig. 1b) with the recovery of slightly less than $40 \%$.

The binding of $\alpha$-CD64-scFv to CD64 at various concentrations was assessed by ELISA. In Fig. 1c, there was a sharp increase of absorbance from 0 to $1.0 \mathrm{ng} / \mathrm{mL}$ and then the absorbance remained constant even though the concentration of CD64 was increased to $10 \mathrm{ng} / \mathrm{mL}$. This suggested that there was a direct proportional
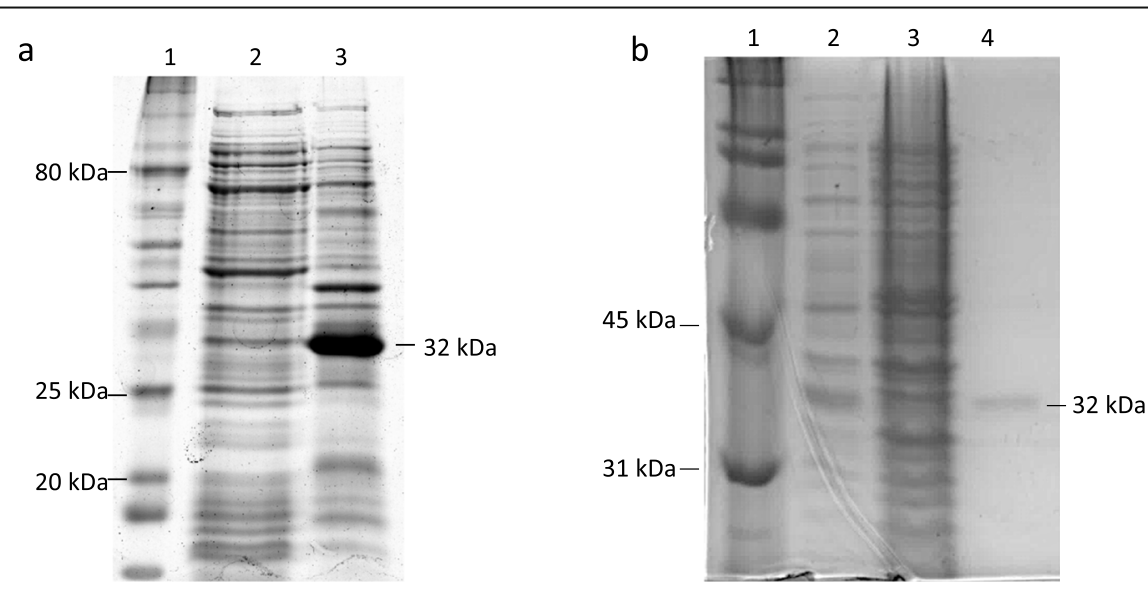

c

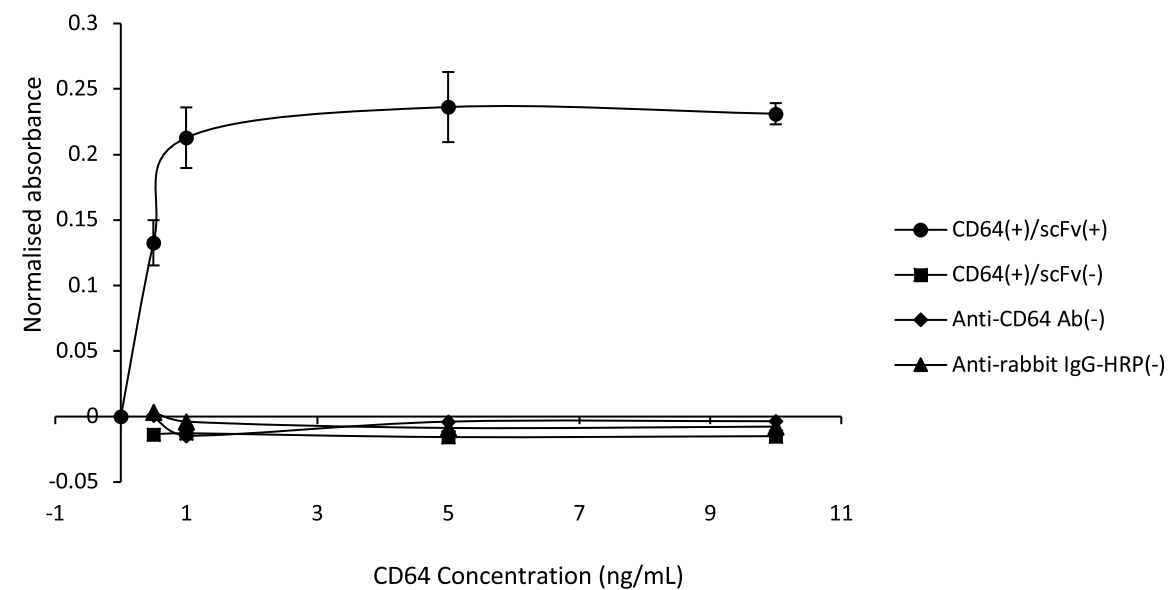

Fig. 1 12\% SDS-PAGE image and binding assay of a-CD64 scFv. a Expression of recombinant a-CD64-scFv. Lane 1, 10-250 kDa protein ladder; lane 2, soluble fraction; lane 3, insoluble fraction. The expected band of $32 \mathrm{kDa}$ was observed in the insoluble fraction. $\mathbf{b}$ a-CD64-scFv after refolding in a series of deceasing urea concentrations. Lane 1, protein ladder, lane 2, E. coli cell lysate with the induction of IPTG; lane 3, E. coli cell lysate without IPTG, and lane 4, refolded a-CD64 scFv visible as the band of $32 \mathrm{kDa}$. c ELISA assay of a-CD64 scFv binding against various concentrations of CD64 (0, 0.5, 1.0, 5.0 and $10 \mathrm{ng} / \mathrm{mL})$. Maximum binding $(0.2362)$ was achieved at $5 \mathrm{ng} / \mathrm{mL}$ of CD64. Each point is the mean generated from triplicate reactions. The controls (no scFv, no anti-CD64 Ab, and no anti-rabbit lgG-HRP) showed no absorbance signal. See also Figure S1; Additional file 2 
relationship between CD64 concentration and binding to $\alpha-\mathrm{CD} 64-\mathrm{scFv}$. As such, $\alpha-\mathrm{CD} 64-\mathrm{scFv}$ is a potential vehicle for immunotoxin to be targeted to M1 macrophages and could be used in the production of immunotoxin.

\section{CD64-binding and cytotoxicity of HALT-1-scFv and sCFv- HALT-1}

Two recombinant immunotoxins with opposite orientations of $\alpha-\mathrm{CD} 64-\mathrm{scFv}$ and HALT-1 were constructed, one with HALT- 1 at the N-terminus and $\alpha-\mathrm{CD} 64-\mathrm{scFv}$ at the C-terminus, and the other having HALT-1 at the $\mathrm{C}$-terminus and $\alpha$-CD64-scFv at the $\mathrm{N}$-terminus. Figure 2 shows the schematic drawing of the recombinant immunotoxins in pET22b expression vector. Orientation of $\alpha$ CD64-scFv and HALT-1 would determine whether or not the recombinant immunotoxin can be produced in E. coli and bind on the cell membrane to form the oligomeric pores. Many known immunotoxins have their own preference of moiety orientation. For instance, Pseudomonas exotoxin A is often positioned at the Cterminal end of immunotoxin [29, 30] whereas Diphtheria toxin tends to be placed at the $\mathrm{N}$-terminal end [31, 32]. In this study, we prepared the recombinant immunotoxin in two different orientations in such that one might work better than the other.

Both recombinant immunotoxins were successfully expressed in BL21(DE3) E. coli cells in the presence of 1 mM IPTG (Fig. 3a and b). However, both recombinant immunotoxins were present in insoluble inclusion bodies (Fig. 3c and d). The insoluble inclusion bodies were isolated, denatured, and purified with Ni-NTA column before the refolding procedure. Stepwise dialysis refolding was processed over a long period of time to achieve high refolding efficiency and recovery of bioactive immunotoxin. Then we confirmed their purity by SDSPAGE (Fig. 3e and $\mathrm{f}$ ). The total yield after refolding was below $40 \%$, indicating that less than $40 \%$ of recombinant immunotoxins were refolded properly, soluble and biologically active (Supplementary Table 3 ). Those that left unfolded or misfolded would remain as aggregates.

To evaluate whether $\alpha-\mathrm{CD} 64-\mathrm{scFv}$ is still able to bind CD64 after it has coupled with HALT-1 in the immunotoxin, we did an ELISA assay. A CD64-coated 96-well immunoplate was treated with various concentrations of the recombinant immunotoxins, HALT-1-scFv and scFv-HALT-1. Our results showed concentrationdependent binding of recombinant HALT-1-scFv to CD64 from 0 to $10 \mu \mathrm{g} / \mathrm{mL}$ (Fig. 4a). Although HALT-1$\mathrm{scFv}$ also showed weaker non-specific binding towards 3\% BSA in CD64(-) control wells, its binding to CD64 was significantly one-fold higher as compared with CD64(-) control (One Way Repeated Measures ANOVA $p=0.0381$ ) (Fig. 4a). scFv-HALT-1, on the other hand, showed no binding to CD64 (Fig. 4b). This might be due to the incorrect folding of $\alpha-\mathrm{CD} 64-\mathrm{scFv}$ during the refolding step and subsequent loss of its binding activity towards CD64. Figure 4c demonstrated that the HALT-1 moiety did not contribute to the CD64 binding of the recombinant immunotoxins.

Cytotoxicity of the recombinant immunotoxins were assessed in vitro by measuring viability of $\mathrm{CD}_{6} 4^{+} \mathrm{M} 1-$ like macrophages and CD64- HeLa cells treated with various concentrations of immunotoxins. Before proceeding with the cytotoxicity assay, PCR was utilized to validate the expression of CD64 in activated M1-like macrophages as well as the lack of CD64 expression in CD64- HeLa cells. The results clearly demonstrated the expression of CD64 in M1-like macrophages and the lack of CD64 expression in HeLa cells (Fig. 5a). Figure $5 \mathrm{~b}, \mathrm{c}$ and $\mathrm{d}$ display the viability of $\mathrm{CD} 64^{+}$M1-like macrophages and CD64 ${ }^{-}$HeLa cells following treatment with increasing concentrations of HALT-1, HALT-1scFv and scFv-HALT-1. CD64 ${ }^{+}$M1-like macrophages are slightly more susceptible than $\mathrm{CD}^{-} 4^{-} \mathrm{HeLa}$ cells to the cytotoxicity of HALT-1, either alone or in

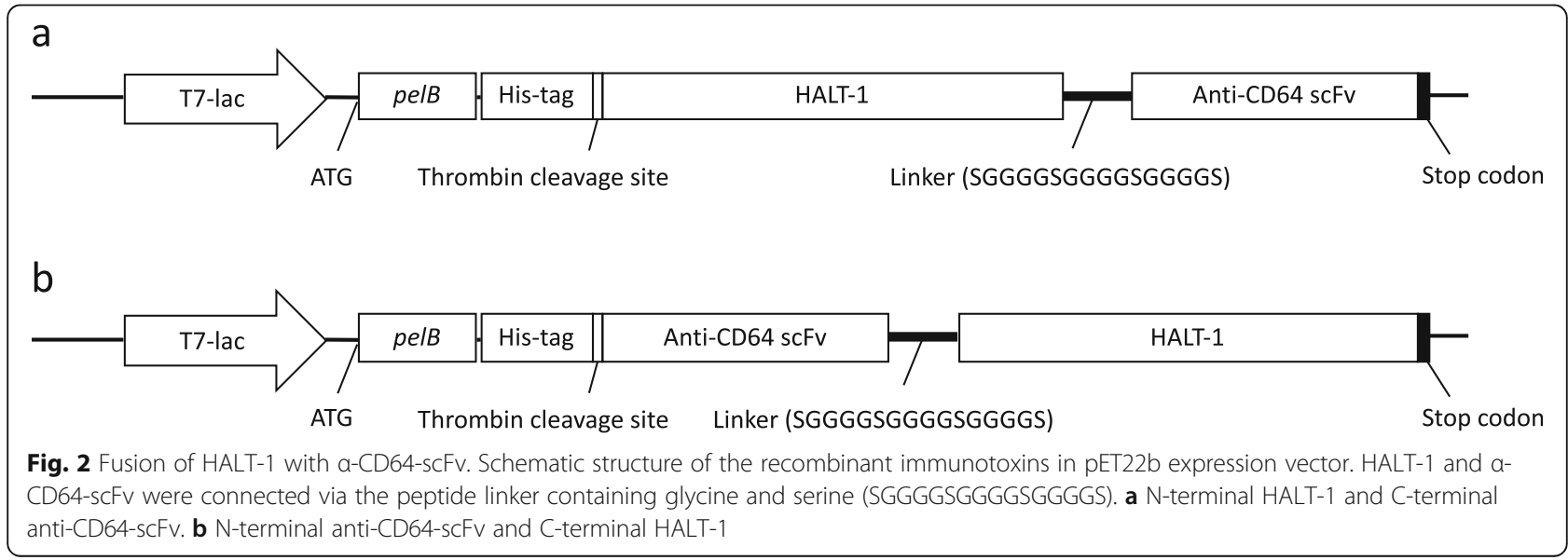




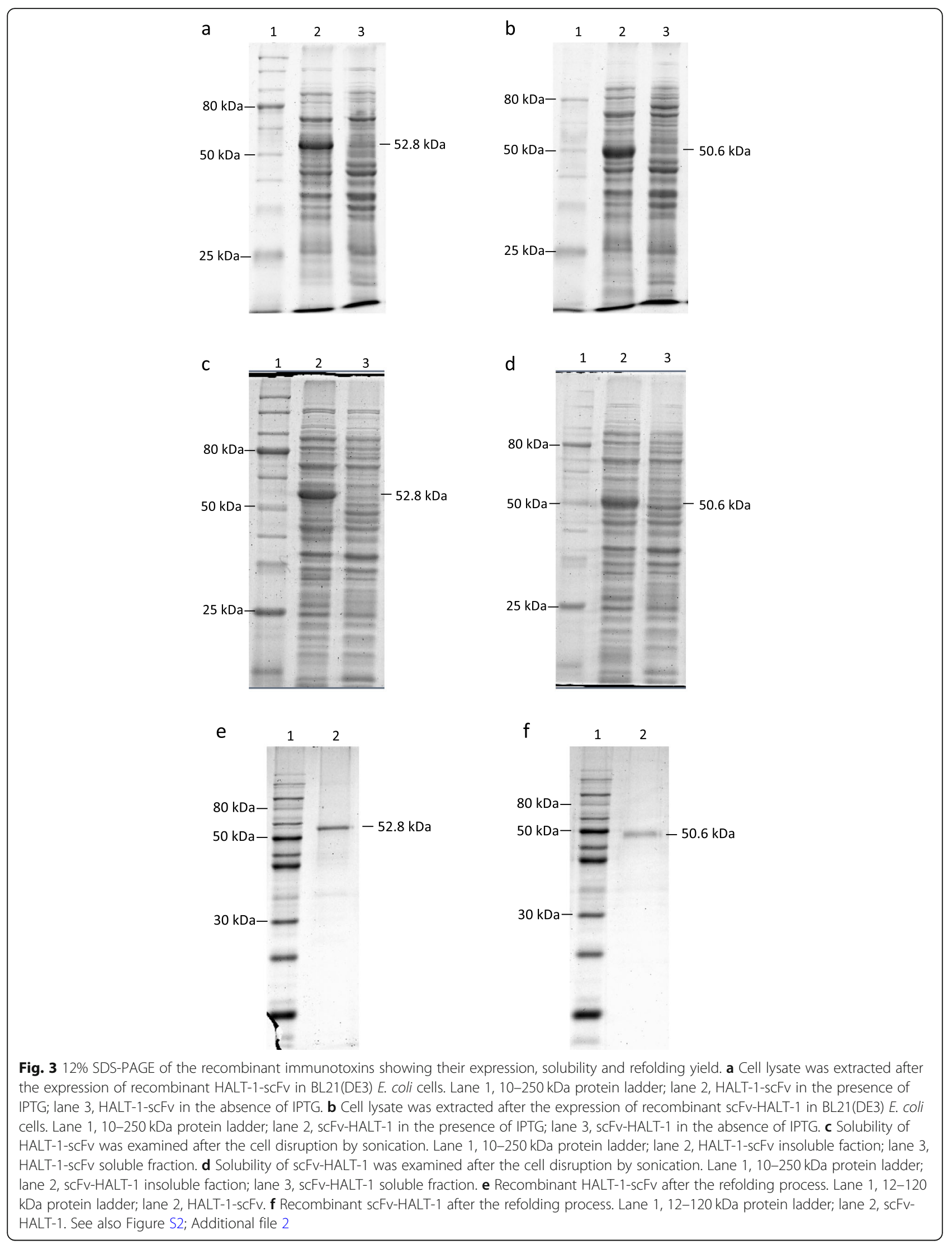




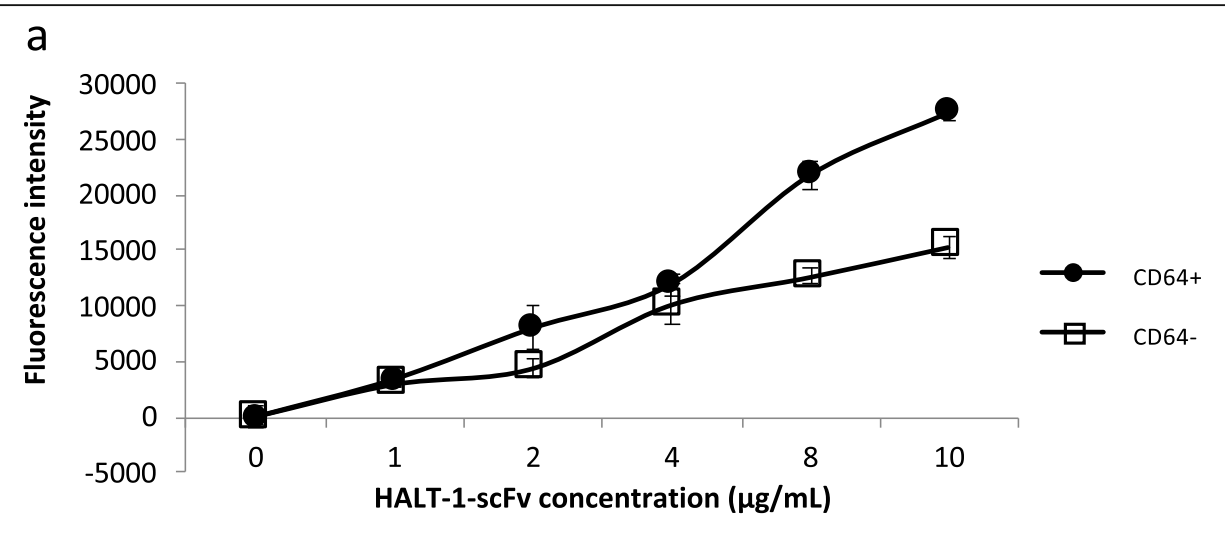

b

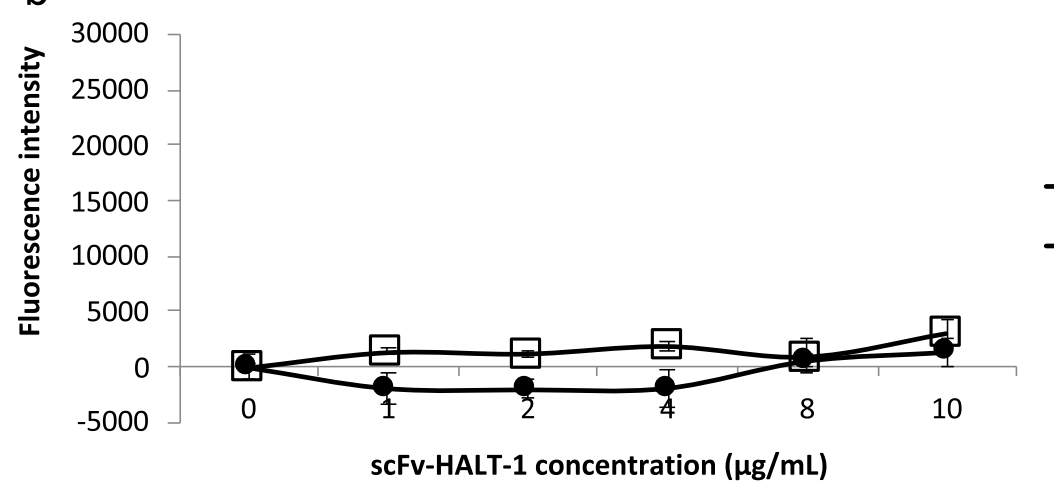

C

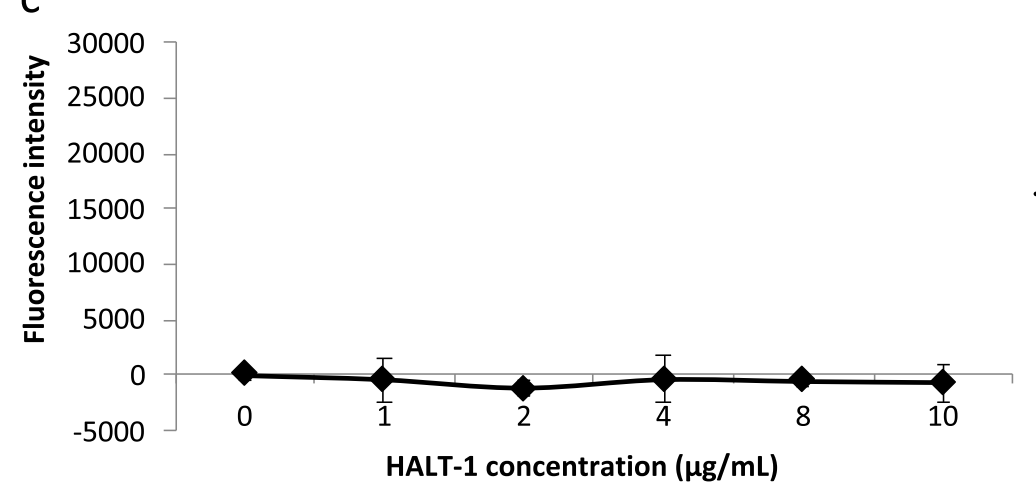

Fig. 4 ELISA assay of CD64 binding to recombinant immunotoxins. a HALT-1-sCFv; b SCFV-HALT-1; c HALT-1. Various concentrations of HALT-1scFv, scFv-HALT-1 and HALT-1 (0, 1, 2, 4, 8 and $10 \mu \mathrm{g} / \mathrm{mL})$ were used in the assay with or without CD64. Each assay was performed in triplicate and error bars represent standard deviations from the mean of triplicate. Recombinant HALT-1 alone was used as a control to indicate that nonspecific binding did not occur between HALT-1 and CD64. Fluorescence intensity was obtained by subtracting the fluorescence value with $0 \mu \mathrm{g} /$ $\mathrm{mL}$ of either HALT-1-scFv, scFv-HALT-1 or HALT-1

conjugation with scFv (Fig. 5b, c and d). HALT-1 toxin alone has an $\mathrm{IC}_{50}$ of $5.05 \mu \mathrm{g} / \mathrm{mL}$ against $\mathrm{CD}^{+} 4^{+} \mathrm{M} 1-$ like macrophages and $12.55 \mu \mathrm{g} / \mathrm{mL}$ against $\mathrm{CD}^{-} 4^{-}$ HeLa cells (Fig. 5b). HALT-1-scFv was shown to have cytolytic activity with $\mathrm{IC}_{50}$ of approximately $10.05 \mu \mathrm{g} /$ $\mathrm{mL}$ on $\mathrm{CD}_{64}^{+}$M1-like macrophages while its $\mathrm{IC}_{50}$ towards CD64- $\mathrm{HeLa}$ cells was found at $17.95 \mu \mathrm{g} / \mathrm{mL}$ (Fig. 5c). Despite the absence of CD64 on the cell membrane of $\mathrm{CD}^{-} 4^{-} \mathrm{HeLa}$ cells, HALT-1-scFv still exerted cytotoxicity as the HALT-1 moiety could recognise its target sites on the cell membrane. Both $\mathrm{CD}_{4}{ }^{+}$and $\mathrm{CD}^{-} 4^{-}$cells were also killed by scFvHALT-1 at $\mathrm{IC}_{50}$ of $9.95 \mu \mathrm{g} / \mathrm{mL}$ and $18.8 \mu \mathrm{g} / \mathrm{mL}$, respectively (Fig. $5 \mathrm{~d}$ ). Since scFv-HALT-1 immunotoxin did not bind CD64 (Fig. 4b), this cytotoxicity must be due to the activity of the HALT-1 moiety. Therefore, the immunotoxins that we constructed in this study reduced the cell viability of $\mathrm{CD}^{+} 4^{+}$and $\mathrm{CD}^{-} 4^{-}$cells, but whether they selectively target $\mathrm{CD}^{+} 4^{+}$cells would 


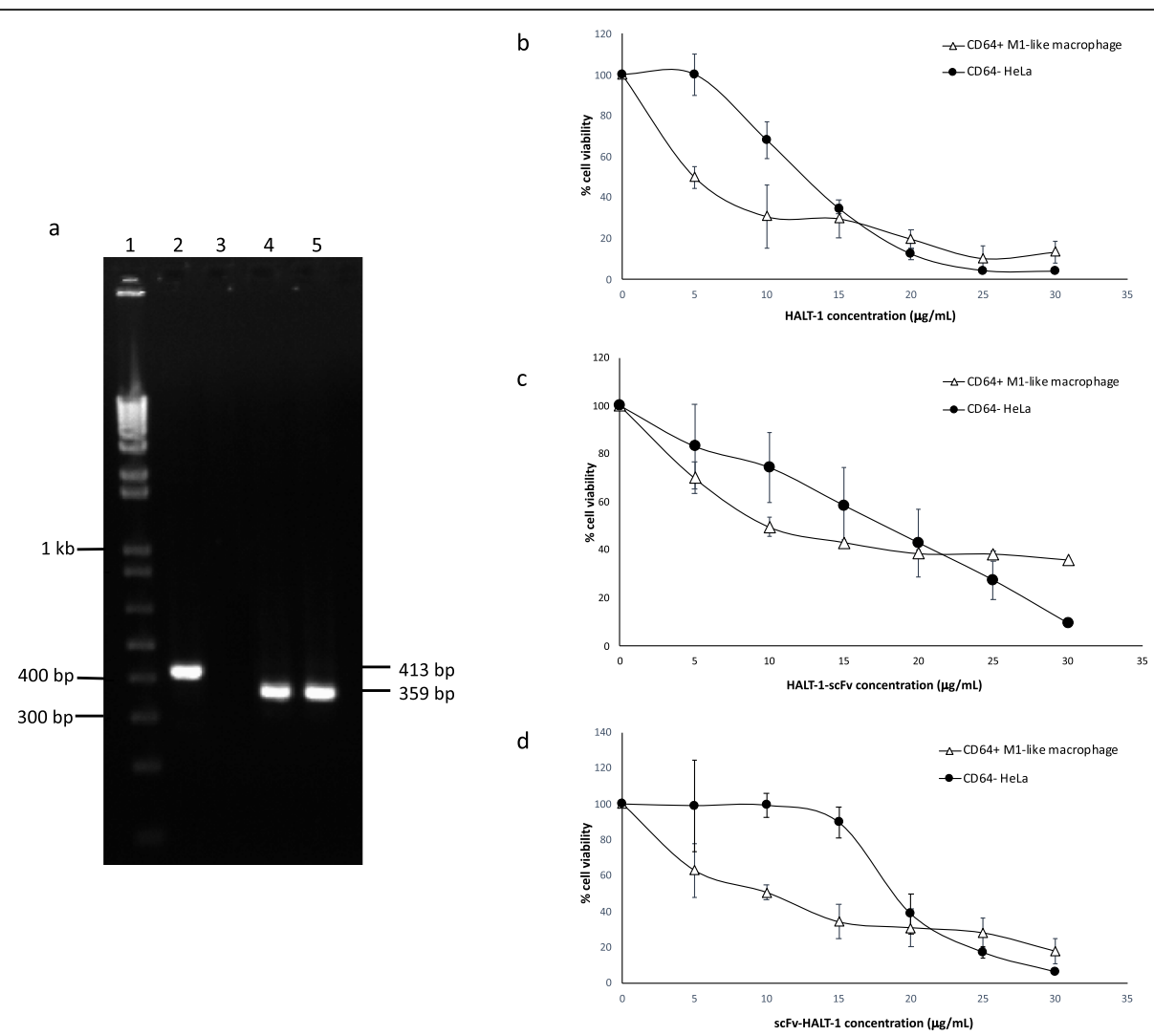

Fig. 5 Cytotoxicity of recombinant immunotoxins towards CD64 M1-like macrophages and CD64 ${ }^{-}$HeLa cells. a PCR validation of CD64 expression. Lane 1, 1 kb plus DNA ladder; lane 2, CD64 expression in M1-like macrophage; lane 3, CD64 expression in HeLa cells; lane 4, GAPDH expression in M1-like macrophage; lane 5, GAPDH expression in HeLa cells. b, c, d Cytotoxicity of HALT-1 alone and recombinant immunotoxins was measured at increasing concentrations $(0,5,10,15,20,25$ and $30 \mu \mathrm{g} / \mathrm{mL})$ against CD64 ${ }^{+} \mathrm{M1} 1$-like macrophages and CD64 ${ }^{-}$HeLa cells. b HALT-1; c HALT-1-SCFv; d sCFv-HALT-1. Data are presented as mean \pm standard deviations from triplicate experiments. See also Figure S3; Additional file 2

require more study using mutant HALT-1 lacking receptor-binding activity.

Taken together these results showed that there were only small differences in the cell viability between cells treated with the two immunotoxins and HALT-1. This supports two conclusions: (1) the toxicity of HALT-1 was not significantly altered by the presence of $\mathrm{scFv}$ moiety in the recombinant immunotoxin and (2) the toxicity of immunotoxins was due primarily to HALT-1 binding to cells and was independent of the presence (M1-like macrophage) or absence (HeLa cells) of CD64 on the cell membrane.

\section{Discussion}

Recombinant immunotoxins were successfully constructed by molecular fusion of HALT-1 and $\alpha$-CD64$\mathrm{scFv}$ via a flexible linker (Fig. 2). The serine and glycinerich linker was selected due to several reasons; (1) flexible glycine-rich regions have been observed as natural linkers in multidomain proteins; (2) glycine and serine provide good flexibility due to their small sizes; (3) serine and glycine help maintain stability of the linker structure in the aqueous solvent by forming hydrogen bonds with water; (4) linker length is within the optimal length of 6 or $10 \pm 5.8$ residues [33, 34]. As stated above, pET22b expression vector was chosen because it contains pelB leader sequence to bring the protein to periplasmic space for disulfide bonds formation [35]. Both recombinant immunotoxins were expected to have the molecular weight of $50.6 \mathrm{kDa}$. However, the SDS-PAGE results indicated that the molecular weights of HALT-1$\mathrm{ScFv}$ was larger than expected (approximately $52.8 \mathrm{kDa}$, Fig. 3a) while the molecular weight of scFv-HALT-1 had the approximately correct size of $50.6 \mathrm{kDa}$ (Fig. 3b). The increase in molecular weight of HALT-1-scFv is likely caused by the failure of the pelB leader sequence (approximately $2.2 \mathrm{kDa}$ ) to be cleaved off during expression. This result was corroborated with the subsequent solubility test (Fig. 3c) showing these immunotoxins were expressed as insoluble inclusion bodies which reflected 
the failure of periplasmic translocation and cleavage of pelB leader sequence. However, despite the successful cleavage of pelB leader sequence, scFv-HALT-1 was also present in the inclusion body (Fig. 3d). In future studies, eukaryotic expression system such as green alga could be used to improve the production and solubility of the recombinant immunotoxins [36].

Refolded recombinant HALT-1-scFv, but not scFvHALT-1, showed in vitro binding to CD64. This suggested that HALT-1-scFv where HALT- 1 and $\alpha$-CD64scFv were placed at the $\mathrm{N}$-terminus and $\mathrm{C}$-terminus, respectively, could be selected for further development of immunotoxin. However, HALT-1-scFv also showed significant degree of non-specific binding towards BSA. Reports have shown that different antibodies and proteins may exert cross-reactivity with BSA [37, 38]. The nonspecific cross-reactivity towards BSA in our results might be one of the rare examples. Additionally, previous report has also shown that glycerol may differentially affect antibody-antigen interaction depending on the antibody clone and antigen [39]. The high concentration of glycerol used in our desalting buffer during the protein refolding may contribute to the signal in CD64(-) ELISA. Expression system that eliminates the need to refold the recombinant immunotoxin or an improved redox refolding system could eliminate the need of glycerol in the refolding protocol.

Our study aims to demonstrate whether HALT-1 could maintain its cytotoxic function after it was conjugated to the $\mathrm{scFv}$ if the conjugated $\mathrm{scFv}$ preserves its target binding capability, and what orientation of HALT-1 in recombinant immunotoxin that gives the highest efficacy in killing the target cells. A number of recombinant immunotoxins targeting CD64 have been developed and reported in several studies as listed in Table 1. Compared to $\mathrm{H} 22(\mathrm{scFv})-\mathrm{ETA}, \mathrm{H} 22(\mathrm{scFv}) 2-\mathrm{ETA}$, granzymeB$\mathrm{H} 22\left(\mathrm{scFv}\right.$ ), and $\mathrm{H} 22(\mathrm{scFv})-\mathrm{MAP}$, the $\mathrm{IC}_{50}$ of HALT-1$\mathrm{scFv}$ was significantly higher at approximately $189 \mathrm{nM}$ (equivalent to $10.05 \mu \mathrm{g} / \mathrm{mL}$ ). This significantly higher working concentration can be explained by the

Table $1 \mathrm{IC}_{50}$ of CD64 targeted recombinant immunotoxins

\begin{tabular}{llll}
\hline Recombinant immunotoxin & Cell line & $\mathrm{IC}_{50}(\mathrm{nM})$ & References \\
\hline H22(scFv)-ETA & HL60 & 0.17 & {$[26]$} \\
H22(scFv)-ETA & U937 & 0.14 & {$[25]$} \\
H22(scFv)2-ETA & U937 & 0.014 & {$[25]$} \\
granzymeB-H22(scFv) & U937 & $1.7-17$ & {$[40]$} \\
H22(scFv)-MAP & HL60 & 0.04 & {$[27]$} \\
HALT-1-scFv & THP-1 & 189 & This study \\
HALT-1-scFv & HeLa & 339.96 & This study \\
scFv-HALT-1 & THP-1 & 196.64 & This study \\
scFv-HALT-1 & HeLa & 371.54 & This study \\
\hline
\end{tabular}

requirement of four or more monomers of HALT-1 to oligomerize in close proximity to form a functional pore and induce cell lysis. Albeit the higher working concentration, HALT-1 based recombinant immunotoxin can be beneficial in selective toxicity. Since at least four monomers of HALT-1 are needed to oligomerize in close proximity, the recombinant immunotoxin could presumably have low cytolytic activity when cells have low and sparse expression of the target surface receptor. As such, HALT-1 based immunotoxin targeting CD64 can selectively eliminate M1-like macrophage that express high amount of the surface receptor. When comparing the cytotoxic activity of HALT-1 before and after conjugating with $\alpha-\mathrm{CD} 64-\mathrm{scFv}$, either HALT-1-scFv or scFv-HALT-1 displayed a two times lower cytotoxic activity than that observed for HALT-1 (Fig. 5). This is not surprising because the reduction of activity was also observed in GFP conjugated equinatoxin II (GFP-EqtII). The fusion of GFP to the C-terminus of equinatoxin II caused the toxin becoming less haemolytic than the native toxin [41]. Despite the opposite orientations, HALT1 in HALT-1-scFv and scFv-HALT-1 demonstrated similar cytotoxic activity in either $\mathrm{CD}^{+} 4^{+} \mathrm{M} 1$-like macrophages $\left(\mathrm{IC}_{50}=10.05\right.$ and $9.95 \mu \mathrm{g} / \mathrm{mL}$, respectively) or CD64 ${ }^{-}$HeLa cells $\left(\mathrm{IC}_{50}=17.95\right.$ and $18.80 \mu \mathrm{g} / \mathrm{mL}$, respectively). One may expect scFv-HALT-1 to have much less activity than HALT-1-scFv since the N-terminus of HALT-1 is functionally important. The role of $\mathrm{N}$ terminal $\alpha$-helix of actinoporin has been previously reported for equinatoxin II. Gutierréz-Aguirre et al. [42] has shown that equinatoxin II mutant having substitution of valine at position 22 to tryptophan (V22W) could establish interactions with the interface of membrane and prevent it from insertion into the lipid bilayer. Similarly, the $\mathrm{N}$-terminal $\alpha$-helix of double cysteine mutant 8-69 (V8C and $\mathrm{K} 69 \mathrm{C}$ ) of equinatoxin II was immobilised in the oxidised form but regained lipid penetration in the reduced form [43]. The initial binding of mutant 8-69 on lipid membrane was not affected under the oxidative condition, indicating that the $\mathrm{N}$-terminal $\alpha$-helix is only involved in the second stage of membrane insertion [43]. Thus, the addition of bulky scFv to the $\mathrm{N}$ terminus of HALT-1 might hinder the detachment of Nterminal helix from the core protein and subsequently its insertion into the lipid bilayer. However, the cytolytic activity of scFv-HALT-1 did not seem to be affected by the fusion of scFv. Having said that, scFv-HALT-1 may not be the choice of immunotoxin because it failed to bind CD64 in vitro in this study. Furthermore, HALT-1 exerted different cytotoxic activities against different human cell lines regardless whether it was connected to a single-chain scFv or not [44]. In our case, HALT-1 worked more effectively in M1-like macrophages than in HeLa cells (Fig. 5). In the next course of development, 
we will introduce mutation(s) in the receptor binding domain of HALT-1 so that the immunotoxin would be directed by its targeting moiety to CD64 expressing cells. Two residues of HALT-1, tryptophan at position 113 and tyrosine at position 129, have been previously substituted into alanine respectively and these mutants, which did not bind membrane lipid, are appropriate candidates as the toxin component of immunotoxin [45]. Moreover, flow cytometry can be introduced to evaluate the binding of HALT-1-scFv or scFv-HALT-1 to CD64 expressing cells in comparison with the commercial anti-CD64 antibody. Lastly, that efficacy of HALT-1 based recombinant immunotoxin can be improved by modification of the scFv moiety to bivalent tandem scFv. Bivalent tandem $\mathrm{H} 22(\mathrm{scFv}) 2$-ETA showed ten folds reduction in $\mathrm{IC}_{50}$ compared to $\mathrm{H} 22(\mathrm{scFv})$-ETA [25].

Almost all toxins currently used in developing recombinant immunotoxins require internalization to cytosol to exert their toxicity, which could lead to degradation of the immunotoxin in lysosome. By comparison, HALT-1 works on the cell surface without the needs for internalization into the cytosol, which avoids the complexity of entry mechanism and the degradation in lysosome. It has been argued that the necrotic action of HALT-1 could cause intracellular components to induce an inflammatory response in the neighbouring cells [46]. Recently, it became clear that HALT- 1 at $\mathrm{IC}_{50}(0.51 \mu \mathrm{M}$ or $10.61 \mu \mathrm{g} / \mathrm{mL}$ ) could also induce an apoptotic pathway in HeLa cells and that the same apoptotic effect could be induced in other cell lines with similar $\mathrm{IC}_{50}$ values [44]. Hence, apoptosis could occur in HALT-1 treated cells when sub-lytic concentration of HALT-1 was used [44]. Interestingly, the apoptotic pathway induced by HALT-1 might not require the internalization of toxin. Recent studies of sticholysin II, a member of actinoporin family as mentioned above, have proven that the pore formation, if not for cell lysis, would lead to the ion efflux which subsequently activates the apoptotic signalling pathway $[11,12]$. This feature differs HALT-1 from other bacterial $\alpha$-PFT and thus HALT- 1 can be an alternative candidate for the construction of immunotoxins.

\section{Conclusions}

We fused HALT- 1 to $\alpha$-CD64-scFv via a flexible linker peptide and demonstrated that HALT-1 could be utilized as a toxin moiety in recombinant immunotoxins. Our preliminary data suggested that the positioning of $\alpha-\mathrm{CD} 64-\mathrm{scFv}$ in immunotoxin is crucial for its binding to CD64 and HALT-1 has reduced half of its cytotoxicity following the conjugation with $\alpha$-CD64-scFv. Despite the limitations, the small molecular size of HALT-1 and the ability to exert its toxicity without the need to be internalized, HALT-1 could be advantages compared to the toxins commonly used in the construction of recombinant immunotoxins.

\section{Methods \\ Recombinant a-CD64 scFv}

Humanised anti-CD64-scFv sequence was obtained from Genbank with the accession number AY585869. To synthesize $\alpha-C D 64-s c F v$, its sequence was optimized using IDT DNA's codon optimization tools for optimum expression in E. coli. The gene was synthesized by IDT DNA (USA) and then placed in PIDT-sMART vector. In order to express the recombinant scFv, the gene was digested with NheI and NdeI and subcloned into pET28a. Finally the cloned plasmid was transformed into BL21(DE3) E. coli cells.

\section{Recombinant HALT-1}

Our group had previously constructed recombinant HALT-1 in pET28a and successfully expressed it in BL21(DE3) E. coli cells and purified it with the $\mathrm{Ni}^{2+}$ affinity chromatography [45].

\section{Construction of recombinant immunotoxins}

Fusion of HALT-1 to $\alpha-\mathrm{CD} 64-\mathrm{scFv}$ as well as introducing the glycine-serine peptide linker (SGGGGSGGGG SGGGGS) were performed by overlap extension polymerase chain reaction (OE-PCR) and could result in two different orientations, HALT-1 at N-terminus followed by $\alpha-C D 64-s c F v$ or vice versa (Fig.2a and b). Basic steps to achieve the different oriented fusion proteins are the same. Firstly, extension PCR was performed on HALT-1 and $\alpha-\mathrm{CD} 64-\mathrm{scFv}$ using Pfu DNA polymerase (Nex-Bio, Malaysia) and two sets of primers for each orientation were prepared to introduce N-terminal His-tag, restriction enzyme sites and linker sequence (Supplementary Table 1). In brief, PCR started at $95^{\circ} \mathrm{C}$ for $5 \mathrm{~min}$, one cycle of $95^{\circ} \mathrm{C}$ for $30 \mathrm{~s}, 50^{\circ} \mathrm{C}$ for $30 \mathrm{~s}, 72^{\circ} \mathrm{C}$ for $1 \mathrm{~min}$ and $30 \mathrm{~s}$; and repeated for 35 cycles at $95^{\circ} \mathrm{C}$ for $30 \mathrm{~s}, 58^{\circ} \mathrm{C}$ for $30 \mathrm{~s}$ and $72{ }^{\circ} \mathrm{C}$ for $1 \mathrm{~min}$ and $30 \mathrm{~s}$; and finally ended with $72{ }^{\circ} \mathrm{C}$ for $5 \mathrm{~min}$. After extension PCR was performed, PCR products were fused in assembly PCR. Assembly PCR started at $95^{\circ} \mathrm{C}$ for $5 \mathrm{~min}$ repeated for 15 cycles at $95^{\circ} \mathrm{C}$ for $1 \mathrm{~min}, 60^{\circ} \mathrm{C}$ for $45 \mathrm{~s}$ and $72^{\circ} \mathrm{C}$ for 1 min and $30 \mathrm{~s}$; and finally ended with $72^{\circ} \mathrm{C}$ for $5 \mathrm{~min}$. After completion of assembly PCR, respective forward and reverse primers were added to the reaction tube and amplification PCR was performed immediately. Briefly, amplification PCR started at $95^{\circ} \mathrm{C}$ for 5 min repeated for 35 cycles at $95^{\circ} \mathrm{C}$ for $1 \mathrm{~min}, 58^{\circ} \mathrm{C}$ for $30 \mathrm{~s}$ and $72^{\circ} \mathrm{C}$ for $2 \mathrm{~min}$ and $30 \mathrm{~s}$; and finally ended with $72^{\circ} \mathrm{C}$ for $5 \mathrm{~min}$. PCR product was run in $1 \%$ agarose gel and desired bands were isolated, followed by purification with Wizard SV gel and PCR clean up system (Promega, USA). After the digestion of $\mathrm{NcoI}$ and $\mathrm{XhoI}$, it was cloned into 
pET22b expression vector and transformed into BL21(DE3) E. coli cells. Plasmid DNA was purified using DNA-spin plasmid purification kit (iNtRON, Korea) and subjected to DNA sequencing for confirmation. In this study, we collectively called both $\alpha$-CD64-scFv-HALT-1 (or scFv-HALT-1) and HALT-1- $\alpha-\mathrm{CD} 64-\mathrm{scFv}$ (or HALT-1-scFv) as the recombinant immunotoxins.

\section{Expression and purification of recombinant a-CD64-scFv and recombinant immunotoxins}

The expression and purification of recombinant $\alpha$ CD64-scFv and recombinant immunotoxins were carried out separately. In general, recombinant protein was expressed in BL21(DE3) E. coli cells in the presence of 1 $\mathrm{mM}$ IPTG at $37^{\circ} \mathrm{C}$ for $3 \mathrm{~h}$. Expressed culture was then re-suspended in Tris-Cl buffer (20 mM; pH 8) containing $1 \mathrm{mM}$ PMSF for sonication. Sonication was performed for a total of $10 \mathrm{~min}$ per sample on ice at 130 watts and $20 \mathrm{kHz}$. Both recombinant anti-CD64-scFv and immunotoxins were present in insoluble fraction. In brief, the insoluble fraction was collected and washed twice for 30 min each with inclusion body washing buffer (2 M urea; $20 \mathrm{mM}$ Tris-Cl; $0.5 \mathrm{M} \mathrm{NaCl} ; 2 \%$ Triton X-100; pH 8) followed by final washing with ice-cold Tris-Cl $(20 \mathrm{mM}$; $\mathrm{pH}$ 8). Washed inclusion bodies were solubilized in solubilization buffer ( $8 \mathrm{M}$ urea; $20 \mathrm{mM}$ sodium phosphate; $50 \mathrm{mM}$ 2-mercaptoethanol; $\mathrm{pH} 7.8$ ) overnight at room temperature. Solubilized inclusion bodies were purified using Nickel NTA (Ni-NTA) resin (Qiagen, Germany) by $\mathrm{pH}$ gradient. Briefly, solubilized inclusion bodies were bound to the resin followed by washing and elution with purification buffer (8M urea; $20 \mathrm{mM}$ sodium phosphate; $0.5 \mathrm{M} \mathrm{NaCl} ; 20 \mathrm{mM} \quad 2$ mercaptoethanol) with reducing $\mathrm{pH}(\mathrm{pH} 7.8, \mathrm{pH} 6, \mathrm{pH}$ 5.5 and $\mathrm{pH} 4.5$ ). Elution fractions were subjected to SDS-PAGE electrophoresis and fractions with purified protein were pooled together for refolding.

\section{Protein refolding for recombinant a-CD64-scFv and immunotoxins}

Recombinant protein purified in denaturing condition was refolded by stepwise dialysis in sodium phosphate buffer containing $0.5 \mathrm{M} \mathrm{NaCl}, 0.1 \mathrm{M}$ (for 6 and $4 \mathrm{M}$ of urea) or $0.5 \mathrm{M}$ (for 2 and $1 \mathrm{M}$ of urea) L-arginine and 50 $\mathrm{mM}$ 2-mercaptoethanol with decreasing concentration of urea (6, 4, 2 and $1 \mathrm{M}$ ) (Supplementary Table 2). Dialysis was performed with gentle stirring on ice for $3 \mathrm{~h}$ each buffer change until $1 \mathrm{M}$ urea buffer which was done overnight followed by three changes of $1 \mathrm{X}$ PBS containing $30 \%$ glycerol for $3 \mathrm{~h}$ each. Without the addition of glycerol, $100 \%$ of the recombinant immunotoxins aggregated in the final desalting (data not shown).

\section{ELISA binding assays}

To show $\alpha-\mathrm{CD} 64-\mathrm{scF}$ is specific for recombinant human CD64 (Sino Biological, USA), their interaction was demonstrated by the enzyme-linked immunosorbent assay (ELISA). In a 96-well microplate, wells were coated with $10 \mu \mathrm{g} / \mathrm{mL}$ of $\alpha-\mathrm{CD} 64-\mathrm{scFv}$ overnight at $4{ }^{\circ} \mathrm{C}$. The unoccupied protein-binding site was then blocked by $3 \%$ $(\mathrm{w} / \mathrm{v})$ BSA/PBS and further incubation at room temperature for $2 \mathrm{~h}$. After rinsing the wells, various concentrations of recombinant CD64 (0, 0.5, 1.0, 5.0 and 10 $\mathrm{ng} / \mathrm{mL}$ ) were added to the wells and incubated at room temperature for $2 \mathrm{~h}$. To visualize the $\alpha-\mathrm{CD} 64-\mathrm{scFv}$ and CD64 interaction, rabbit anti-CD64 polyclonal antibody (Invitrogen, USA) was added to each well, and followed by anti-rabbit HRP complex (1: 5000) and TMB substrate complex (Thermo-Fisher, USA). The signal produced was read at $370 \mathrm{~nm}$ by multi-mode microplate reader (TECAN, Switzerland). Four negative controls with each lacking a specific component of ELISA, either $\alpha-C D 64-s c F v$, CD64 protein, rabbit $\alpha$-CD64 polyclonal antibody or $\alpha$-rabbit HRP conjugate, were prepared for each 96-well microtiter plate.

ELISA was also performed to determine binding of recombinant immunotoxins to CD64. The basic procedure was carried out as described above. Recombinant human CD64 $(0.5 \mu \mathrm{g} / \mathrm{mL})$ was first coated to a 96 -well microtiter plate. To allow the binding of recombinant immunotoxin to CD64, the recombinant immunotoxin was added to the wells at different concentrations $(0,1,2,4$, 8 and $10 \mu \mathrm{g} / \mathrm{mL})$. By washing the wells in between incubations, rabbit anti-HALT-1 primary antibody $(2.3 \mu \mathrm{g} /$ $\mathrm{mL})$, goat anti-rabbit IgG-AP $(12.5 \mathrm{ng} / \mathrm{mL})$ and 4-MUP (4-methylumbelliferyl phosphate) (Sigma-Aldrich, USA) were added to the wells in a precise sequence of steps. The fluorescence absorbance/exciting readings at 355/ $460 \mathrm{~nm}$ were measured by a multi-mode microplate reader (BMG Labtech, Germany) at 5 min time-point for $30 \mathrm{~min}$. The same experiment was performed without CD64 to ensure that any fluorescence detection is due to the specific binding between CD64 and recombinant immunotoxin. Three negative controls (1) CD64 coated only (2) without primary antibody and (3) without secondary antibody were also included in each set of tests.

\section{Statistical data analysis}

ELISA of HALT-1-scFv was conducted in biological and technical triplicates for each CD64-coated and CD64uncoated wells. The statistical analysis was performed by using $\mathrm{R}$ version 3.6.0 [47] (https://www.R-project.org/). The consistency of biological triplicate experiments was examined by using One-Way Repeated Measures ANOVA. In order to distinguish the specificity of HALT-1-scFv to CD64-coated wells from uncoated wells, one tail paired $\mathrm{T}$ test was conducted. For all the 
test conducted, $p \leq 0.05$ was set to define significance of differences.

\section{Polarization of M1-like macrophages}

Cytotoxicity assay of the recombinant immunotoxins was performed on CD64 ${ }^{+}$THP-1 (ATCC TIB-202) human monocyte cell line. Cells were routinely cultured in $20 \mathrm{~mL}$ of Roswell Park Memorial Institute (RPMI 1640) culture medium (Nacalai tesque, Japan) supplemented with $10 \%$ fetal bovine serum (FBS), $100 \mathrm{U} / \mathrm{ml}$ penicillin/ streptomycin, $10 \mathrm{mM}$ hepes, $1 \mathrm{mM}$ pyruvate, and $50 \mathrm{pM}$ 2-mercaptoethanol; and grown at $37^{\circ} \mathrm{C}$ with $5 \% \mathrm{CO}_{2}$. For cytotoxicity assay, cells were seeded at $1 \times 10^{4}$ cells/ well in 96-well microtiter plate with the addition of 200 $\mathrm{nM}$ phorbol 12-myristate 13-acetate (PMA) and incubated for $72 \mathrm{~h}$ to activate the monocytes to macrophages. Activated cells were then polarized to M1-like macrophages by changing the medium to fresh RPMI medium containing $20 \mathrm{ng} / \mathrm{mL}$ of IFN- $\gamma$ and $10 \mathrm{pg} / \mathrm{mL}$ of LPS, followed by incubation for another $48 \mathrm{~h}$. Expression of CD64 in M1-like polarized macrophages were validated by PCR. CD64 specific primers [48] were used to determine the expression of CD64 and GAPDH specific primers [49] were used for amplifying the positive control.

\section{In vitro cytotoxicity assay}

$\mathrm{CD}^{+} 4^{+}$M1-like macrophages were treated with various concentrations of recombinant immunotoxin $(5,10,15$, 20, 25 and $30 \mu \mathrm{g} / \mathrm{mL}$ ). Three controls (1) medium only (negative), (2) medium with cells (negative) and (3) cells added with dimethyl sulfoxide (DMSO) (positive) were included in each set of assays. CD64- HeLa cells were also treated with the same serial concentration of recombinant immunotoxin to assess the unspecific cytotoxicity. MTT (3-(4,5-dimethylthiazol-2-yl)-2,5-diphenyltetrazolium bromide) stock solution $(5 \mathrm{mg} / \mathrm{mL})$ was added to each well and incubated for another $3 \mathrm{~h}$ at $37^{\circ} \mathrm{C}$ with $5 \% \mathrm{CO}_{2}$. The formazan violet crystals were dissolved by addition of $200 \mu \mathrm{L}$ DMSO (99.5\%) followed by measurement at 570 $\mathrm{nm}$ with the reference of $630 \mathrm{~nm}$ using a spectrophotometric microplate reader (Bio-Tek, USA).

\section{Supplementary information}

Supplementary information accompanies this paper at https://doi.org/10. 1186/s12896-020-00628-9.

\footnotetext{
Additional file 1: Supplementary Table 1. List of OE-PCR primers.

Supplementary Table 2. Refolding buffers components.

Supplementary Table 3. Yield of recombinant immunotoxins before and after refolding

Additional file 2: Figure S1. $12 \%$ SDS-PAGE image and binding assay of a-CD64 scFv. These are the original gel images shown in Fig. 1a and b. a Expression of recombinant a-CD64-scFv. Lane 1, 10-250 kDa protein ladder; lane 2, soluble fraction; lane 3, insoluble fraction. The expected
}

band of $32 \mathrm{kDa}$ was observed in the insoluble fraction. $\mathrm{b}$ a-CD64-scFv after refolding in a series of deceasing urea concentrations. Lane 1, protein ladder, lane 2, E. coli cell lysate with the induction of IPTG; lane 3, E. coli cell lysate without IPTG, and lane 4, refolded a-CD64 scFv visible as the band of $32 \mathrm{kDa}$. Figure S2. 12\% SDS-PAGE of the recombinant immunotoxins showing their expression, solubility and refolding yield. These images are the original gel images shown in Fig. 3. Lanes that are not labelled have no direct relevance to the data presented in this study. a Cell lysate was extracted after the expression of recombinant scFvHALT-1 in BL21(DE3) E. coli cells. Lane 1, 10-250 kDa protein ladder; lane 2, scFV-HALT-1 in the presence of IPTG; lane 3, scFv-HALT-1 in the absence of IPTG.b Cell lysate was extracted after the expression of recombinant HALT-1-scFv in BL21(DE3) E. coli cells. Lane 1, 10-250 kDa protein ladder; lane 2, HALT-1-scFv in the presence of IPTG; lane 3, HALT1-scFv in the absence of IPTG. c Solubility of HALT-1-scFv was examined after the cell disruption by sonication. Lane 1, 10-250 kDa protein ladder; lane 2, HALT-1-scFv insoluble faction; lane 3, HALT-1-scFv soluble fraction. d Solubility of scFv-HALT-1 was examined after the cell disruption by sonication. Lane 1, 10-250 kDa protein ladder; lane 2, scFv-HALT-1 insoluble faction; lane 3, scFv-HALT-1 soluble fraction. e Recombinant HALT-1-scFv after the refolding process. Lane 1, 12-120 kDa protein ladder; lane 2, HALT-1-scFv. f Recombinant scFv-HALT-1 after the refolding process. Lane 1, 12-120 kDa protein ladder; lane 2, scFv-HALT-1.

Figure S3. PCR validation of CD64 expression. Gel electrophoresis images are not the original image of Fig. 5a but they were derived from two repeated experiments as that of Fig. 5a. For both $a$ and $b$, lane 1, 1 $\mathrm{kb}$ plus DNA ladder; lane 2, CD64 expression in M1-like macrophage; lane 3, CD64 expression in HeLa cells; lane 4, GAPDH expression in M1-like macrophage; lane 5, GAPDH expression in HeLa cells.

\section{Abbreviations}

4-MUP: 4-methylumbelliferyl phosphate; a-PFT: a-pore forming toxin; ANOVA: Analysis of variance; BSA: Bovine serum albumin; CD64: Cluster of differentiation 64; DMSO: Dimethyl sulfoxide; ELISA: Enzyme-linked immunosorbent assay; ETA: Exfoliative toxin A; FBS: Fetal bovine serum; GAPDH: Glyceraldehyde 3-phosphate dehydrogenase; HALT-1: Hydra actinoporin-like toxin 1; HRP: Horseradish peroxidase; IC50: Half maximal inhibitory concentration; IFN- $\gamma$ : Interferon gamma; IgG-AP: Immunoglobulin G conjugated with alkaline phosphatase; IPTG: Isopropyl $\beta$-D-1-thiogalactopyranoside; kDa: Kilo dalton; MAP: Microtubule-associated protein tau; MTT: 3(4,5-dimethylthiazol-2-yl)-2,5-diphenyltetrazolium bromide; OE-PCR: Overlap extension polymerase chain reaction; PBS: Phosphate buffered saline; PMA: Phorbol 12-myristate 13-acetate; PMSF: Phenylmethylsulfonyl fluoride; RPMI: Roswell Park Memorial Institute; scFv: Single-chain variable fragment; SDS-PAGE: Sodium dodecyl sulfate polyacrylamide gel electrophoresis; TMB: 3,3',5,5'-tetramethylbenzidine

\section{Acknowledgements}

We would like to express our sincere thanks to Dr. Charles N. David for his critical reading and constructive comments of the manuscript.

\section{Authors' contributions}

WFJ carried out most of the experiments and wrote the draft of manuscript; LFH conducted one part of ELISA; HXS performed the statistical analysis; LLAI contributed on the discussion and revision of manuscript; JSH designed the study and wrote the manuscript. All authors have read and approved the manuscript.

\section{Funding}

This work was supported by UCSI University under Research Grant Scheme [Grant no. Proj-In-FAS-020]. The funding body had no role in the design of the study, the collection, analysis, and interpretations of data and in writing the manuscript.

\section{Availability of data and materials}

The datasets used and/or analysed during the current study are available from the corresponding author on reasonable request.

Ethics approval and consent to participate Not applicable. 


\section{Consent for publication}

Not applicable.

\section{Competing interests}

The authors declare no competing interests.

\section{Author details}

'Department of Biotechnology, Faculty of Applied Sciences, UCSI University, 56000 Kuala Lumpur, Malaysia. ${ }^{2}$ Department of Biological Sciences, School of Science and Technology, Sunway University, No. 5, Jalan Universiti, Bandar Sunway, 47500 Selangor Darul Ehsan, Malaysia. ${ }^{3}$ Department of Medical Sciences, School of Healthcare and Medical Sciences, Sunway University, No. 5, Jalan Universiti, Bandar Sunway, 47500 Selangor Darul Ehsan, Malaysia.

\section{Received: 26 March 2020 Accepted: 10 June 2020}

\section{Published online: 17 June 2020}

\section{References}

1. Shapira A, Benhar I, Toxin-based therapeutic approaches. Toxin. 2010;2: 2519-2583. https://doi.org/10.3390/toxins2112519.

2. Słomińska-Wojewódzka M, Sandvig K. Ricin and ricin-containing immunotoxins: insights into intracellular transport and mechanism of action in vitro. Antibodies. 2013:2: 236-269. https://doi.org/10.3390/antib2020236.

3. Du X, Beers R, FitzGerald DJ. Differential cellular internalization of anti-CD19 and -CD22 immunotoxins results in different cytotoxic activity. Cancer Res 2008;68:6300-6305. https://doi.org/10.1158/0008-5472.CAN-08-0461.

4. Glasser E, Rachamim T, Aharonovich D, Sher D. Hydra actinoporin-like toxin1, an unusual hemolysin from the nematocyst venom of Hydra magnipapillata which belongs to an extended gene family. Toxicon. 2014; 91:103-113. https://doi.org/10.1016/j.toxicon.2014.04.004.

5. Podobnik M, Anderluh G. Pore-forming toxins in Cnidaria. Semin Cell Dev Biol 2017;72:133-141. https://doi.org/10.1016/j.semcdb.2017.07.026.

6. Rojko N, Serra MD, Maček P, Anderluh G. Pore formation by actinoporins, cytolysins from sea anemones. Biochim Biophys Acta 2016; 1858:446-456. https://doi.org/10.1016/j.bbamem.2015.09.007.

7. Alvarez C, Ros U, Valle A, Pedrera L, Soto C, Hervis YP, et al. Biophysical and biochemical strategies to understand membrane binding and pore formation by sticholysins, pore-forming proteins from a sea anemone Biophys Rev 2017;9:529-544. https://doi.org/10.1007/s12551-017-0316-0.

8. Avila AD, de Acosta MC, Lage A. A new immunotoxin built by linking a hemolytic toxin to a monoclonal antibody specific for immature $T$ lymphocytes. Int J Cancer 1988;42:568-571. https://doi.org/10.1002/ijc. 2910420417.

9. Tejuca M, Anderluh G, Maček P, Alvarez C, Lanio ME, Marcet R, et al. Antiparasite activity of sea anemone cytolysins on Giardia duodenalis and specific targeting with anti-Giardia antibodies. Int J Parasitol 1999;29:489498. https://doi.org/10.1016/S0020-7519(98)00220-3.

10. Tejuca M, Diaz I, Figueredo R, Roque L, Pazos F, Martinez D, et al. Construction of an immunotoxin with the pore forming protein StI and IOR C5, a monoclonal antibody against a colon cancer cell line. Int Immunopharmacol 2004:4:731-744. https://doi.org/10.1016/.intimp.2004.02.010.

11. Soto $C$, Bergado $G$, Blanco $R$, Griñán $T$, Rodríguez $H$, Ros $U$, et al. Sticholysin II-mediated cytotoxicity involves the activation of regulated intracellular responses that anticipates cell death. Biochimie. 2018;148:18-35. https://doi. org/10.1016/j.biochi.2018.02.006.

12. Cabezas S, Ho S, Ros U, Lanio ML, Alvarez C, van der Goot FG. Damage of eukaryotic cells by the pore-forming toxin sticholysin II: consequences of the potassium efflux. BBA Biomembranes 2017;1859:982-992. https://doi. org/10.1016/j.bbamem.2017.02.001.

13. Jiemy WF, Heeringa P, Kamps JAAM, van der Laken CJ, Slart RHJA, Brouwer E. Positron emission tomography (PET) and single photon emission computed tomography (SPECT) imaging of macrophages in large vessel vasculitis: current status and future prospects. Autoimmun Rev 2018;17:715726. https://doi.org/10.1016/j.autrev.2018.02.006.

14. Cochain C, Zernecke A. Macrophages in vascular inflammation and atherosclerosis. Pflüg Arch Eur J Phy 2017:469:485-499. https://doi.org/10. 1007/s0042

15. Laria A, Lurati A, Marrazza M, Mazzocchi D, Re KA, Scarpellini M. The macrophages in rheumatic diseases. J Inflamm Res 2016;9:1-11. https://doi. org/10.2147/JR.S82320.
16. Labonte AC, Kegerreis B, Geraci NS, Bachali P, Madamanchi S, Robl R, et al Identification of alterations in macrophage activation associated with disease activity in systemic lupus erythematosus. PLoS One 2018;13: e0208132. https://doi.org/10.1371/journal.pone.0208132.

17. Thepen T, Vuuren AJH, Kiekens RCM, Damen CA, Vooijs WC, Winkel JGJ. Resolution of cutaneous inflammation after local elimination of macrophages. Nat Biotech 2000;18:48-51. https://doi.org/10.1038/71908.

18. Weagel E, Smith C, Liu PG, Robison R, O'Neill K. Macrophage polarization and its role in cancer. J Clin Cell Immunol 2015;6:338. http://dx.doi.org/ https://doi.org/10.4172/2155-9899.1000338.

19. Valledor AF, Comalada M, Santamaría-Babi LF, Lloberas J, Celada A. Macrophage proinflammatory activation and deactivation: a question of balance. Adv Immunol 2010;108:1-20. https://doi.org/10.1016/B978-0-12380995-7.00001-X

20. Hristodorov D, Mladenov R, Felbert V, Huhn M, Fischer R, Barth S, Thepen T. Targeting CD64 mediates elimination of M1 but not M2 macrophages in vitro and in cutaneous inflammation in mice and patient biopsies. MAbs. 2015;7:853-862. https://doi.org/10.1080/19420862.2015.1066950.

21. Hulett MD, Hogarth PM. The second and third extracellular domains of FcyRI (CD64) confer the unique high affinity binding of IgG2a. Mol Immunol 1998:35:989-996. https://doi.org/10.1016/S0161-5890(98)00069-8.

22. Akinrinmade OA, Chetty S, Daramola AK, Islam M, Thepen T, Barth S. CD64: an attractive immunotherapeutic target for M1-type macrophage mediated chronic inflammatory diseases. Biomedicines. 2017;5:E56. https://doi.org/10. 3390/biomedicines5030056.

23. Van Roon JAG, van Vuuren AJ, Wijngaarden S, Jacobs KMG, Bijlsma JWJ, Lafeber FPJG, et al. Selective elimination of synovial inflammatory macrophages in rheumatoid arthritis by an Fcy receptor I - directed immunotoxin. Arthritis Rheumatol 2003:48:1229-1238. https://doi.org/10. 1002/art.10940

24. van Vuuren AJ, Roon JAG, Walraven V, Stuij I, Harmsen MC, McLaughlin PMJ et al. CD64-directed immunotoxin inhibits arthritis in a novel CD64 transgenic rat model. J Immunol 2006;176:5833-5838. https://doi.org/10. 4049/jimmunol.176.10.5833.

25. Ribbert T, Thepen T, Tur MK, Fischer R, Huhn M, Barth S. Recombinant ETA '-based CD64 immunotoxins: improved efficacy by increased valency, both in vitro and in vivo in a chronic cutaneous inflammation model in human CD64 transgenic mice. Br J Dermatol 2010;163:279-286. https://doi.org/10. 1111/j.1365-2133.2010.09824.x.

26. Tur MK, Huhn M, Thepen T, Stocker M, Krohn R, Vogel S, et al. Recombinant CD64-specific single chain immunotoxin exhibits specific cytotoxicity against acute myeloid leukemia cells. Cancer Res. 2003;63:8414-9.

27. Hristodorov D, Mladenov R, Fischer R, Barth S, Thepen T. Fully human MAPfusion protein selectively targets and eliminates proliferating CD64(+) M1 macrophages, Immunol Cell Biol 2016;94:470-478. https://doi.org/10.1038/ icb.2016.4

28. Schiffer S, Rosinke R, Jost E, Hehmann-Titt G, Huhn M, Melmer G, et al. Targeted ex vivo reduction of CD64-positive monocytes in chronic myelomonocytic leukemia and acute myelomonocytic leukemia using human granzyme B-based cytolytic fusion proteins. IJC. 2014;135:1497-1508. https://doi.org/10.1002/ijc.28786.

29. Hassan R, Bullock S, Premkumar A, Kreitman RJ, Kindler H, Willingham MC, et al. Phase I study of SS1P, a recombinant anti-mesothelin immunotoxin given as a bolus I.V. infusion to patients with mesothelin-expressing mesothelioma, ovarian, and pancreatic cancers. Clin Cancer Res 2007;13: 5144-5149. https://doi.org/10.1158/1078-0432.CCR-07-0869.

30. Di Paolo C, Willuda J, Kubetzko S, Lauffer I, Tschudi D, Waibel R, et al. A recombinant immunotoxin derived from a humanized epithelial cell adhesion molecule-specific single-chain antibody fragment has potent and selective antitumor activity. Clin Cancer Res. 2003:9:2837-48.

31. Shaw JP, Akiyoshi DE, Arrigo DA, Rhoad AE, Sullivan B, Thomas J, et al. Cytotoxic properties of $\mathrm{DAB}_{486} \mathrm{EGF}$ and $\mathrm{DAB}{ }_{389} \mathrm{EGF}$, epidermal growth factor (EGF) receptor-targeted fusion toxins. J Biol Chem. 1991;266:21118-24.

32. Frankel AE, Ramage J, Kiser M, Alexander R, Kucera G, Miller MS. Characterization of diphtheria fusion proteins targeted to the human interleukin-3 receptor. Protein Eng 2000;13:575-581. https://doi.org/10.1093/ protein/13.8.575

33. Chen X, Zaro J, Shen WC. Fusion protein linkers: property, design and functionality. Adv Drug Deliv Rev 2013;65:1357-1369. https://doi.org/10. 1016/j.addr.2012.09.039 
34. Chichili VPR, Kumar V, Sivaraman J. Linkers in the structural biology of protein-protein interactions. Protein Sci 2013;22:153-167. https://doi.org/10. 1002/pro.2206.

35. Singh P, Sharma L, Kulothungan SR, Adkar BV, Prajapati RS, Ali PS. Effect of signal peptide on stability and folding of Escherichia coli thioredoxin. PLoS One 2013;8:e63442. https://doi.org/10.1371/journal.pone.0063442.

36. Tran M, Van C, Barrera DJ, Pettersson PL, Peinado CD, Bui J, et al. Production of unique immunotoxin cancer therapeutics in algal chloroplasts. Proc Natl Acad Sci U S A 2013;110:E15-E22. https://doi.org/10.1073/pnas.1214638110.

37. Chart H, Evans J, Chalmers RM, Salmon RL. Escherichia coli 0157 serology: false-positive ELISA results caused by human antibodies binding to bovine serum albumin. Lett Appl Microbiol 1998;27:76-78. https://doi.org/10.1046/j. 1472-765X.1998.00396.X.

38. Xiao Y, Isaacs SN. Enzyme-linked immunosorbent assay (ELISA) and blocking with bovine serum albumin (BSA) - not all BSAs are alike. J Immunol Methods 2012;384:148-151. https://doi.org/10.1016/j.jim.2012.06.009.

39. Kjaer S, Stausbøl-Grøn B, Wind T, Ravn P, Jensen KH, Kahns L, et al. Glycerol diversifies phage repertoire selections and lowers non-specific phage absorption. FEBS Lett 1998:431:448-452. https://doi.org/10.1016/S00145793(98)00789-3.

40. Stahnke B, Thepen T, Stöcker M, Rosinke R, Jost E, Fischer R, et al. Granzyme B-H22(scFv), a human immunotoxin targeting CD64 in acute myeloid leukemia of monocytic subtypes. Mol Cancer Ther 2008;7:2924-2932. https://doi.org/10.1158/1535-7163MCT-08-0554.

41. Bakrač A, Kladnik A, Maček P, McHaffie G, Werner A, Lakey J, et al. A toxinbased probe reveals cytoplasmic exposure of Golgi sphingomyelin. J Biol Chem 2010;285:22186-22195. doi: https://doi.org/https://doi.org/10.1074/jbc. M110.105122.

42. Gutierréz-Aguirre I, Barlič A, Podlesek Z, Maček P, Anderluh G, GonzálezMañas JM. Membrane insertion of the $\mathrm{N}$-terminal a-helix of equinatoxin II, a sea anemone cytolytic toxin. Biochem J 2004;384:421-428. https://doi.org/ 10.1042/BJ20040601.

43. Hong Q, Gutierréz-Aguirre I, Barlič A, Malo.vrh P, Kristan K, Podlesek Z, et al. Two-step membrane binding by equinatoxin II, a pore-forming toxin from the sea anemone, involves an exposed aromatic cluster and a flexible helix. J Biol Chem. 2002;277:41916-24. https://doi.org/10.1074/jbc.M204625200.

44. Ng TJ, Teo MYM, Liew DS, Effiong PE, Hwang JS, Lim CSY, In LLA. Cytotoxic and apoptosis-inducing effects of wildtype and mutated Hydra actinoporinlike toxin 1 (HALT-1) on various cancer cell lines. PeerJ. 2019;7:e6639. https://doi.org/10.7717/peerj.6639.

45. Liew JMY, Soh WT, Jiemy WF, Hwang JS. Mutagenesis and functional analysis of the pore-forming toxin HALT-1 from Hydra magnipapillata. Toxins. 2015;7;407-422. https://doi.org/10.3390/toxins7020407.

46. Proskuryakov SY, Konoplyannikov AG, Gabai VL. Necrosis: a specific form of programmed cell death? Exp Cell Res 2003;283:1-16. https://doi.org/10. 1016/S0014-4827(02)00027-7.

47. R Core Team. R. A language and environment for statistical computing. Vienna: R foundation for statistical computing; 2017.

48. Leung HL. Mechanism of antibody-dependent enhancement in severe acute respiratory syndrome coronavirus infection. Thesis. Hong Kong: The University of Hong Kong; 2012.

49. Littlefield MJ, Teboul I, Voloshyna I, Reiss AB. Polarization of human THP-1 macrophages, link between adenosine receptors, inflammation and lipid accumulation. Int J Immunol Immunother. 2014;1:1-8. https://doi.org/10 23937/2378-3672/1410001.

\section{Publisher's Note}

Springer Nature remains neutral with regard to jurisdictional claims in published maps and institutional affiliations.

Ready to submit your research? Choose BMC and benefit from:

- fast, convenient online submission

- thorough peer review by experienced researchers in your field

- rapid publication on acceptance

- support for research data, including large and complex data types

- gold Open Access which fosters wider collaboration and increased citations

- maximum visibility for your research: over $100 \mathrm{M}$ website views per year

At BMC, research is always in progress.

Learn more biomedcentral.com/submissions 